Abstract: In recent decades, literary critics have become increasingly interested in the ways that contemporary historical novels are used to write "history from below." Novelists like Philippa Gregory, Diana Gabaldon, and Tracy Chevalier have made feminist politics clearly visible in their bestselling historical novels in order to reinsert histories of women into the dominant historical narrative from which they are often excluded. And yet, for all their potential and visible disruptions of patriarchal ideology, many of these popular novels also make use of literary archetypes, tropes, and narrative patterns that reinstate hegemonic ideologies Feminist Historical Re-Visioning or "Good Mills and Boon"?: Gender, Genre, and Philippa Gregory's The Other Boleyn Girl Victoria Kennedy about individual identity and social structure. Using Gregory's The Other Boleyn Girl (2001) as a case study, this paper argues that popular women's historical novels often exist in tension between the poles of revisionary feminist historiography and the popular romance narrative.

The act of rewriting history from a woman's perspective is a kind of feminist resistance. Adrienne Rich describes "re-visioning" as a process of "looking back, of seeing with fresh eyes, of entering an old text from a new critical direction" (35). Many female authors of contemporary historical novels engage in exactly this process, looking back in time and reinserting women's stories into dominant historical narratives from which they are often excluded or marginalized. In her 
Feminist Historical Re-Visioning or "Good Mills and Boon"? Pivot 5.1

ground-breaking 2005 study The Woman's Historical Novel, the first comprehensive consideration of women writers working in the genre over the past century, Diana Wallace asserts that the historical genre in fiction has been, since the turn of the twentieth century, "a 'feminine' form" (3). Although women had been writing novels since the 1700s, Wallace suggests that they "turned to the historical novel at the beginning of the [twentieth] century, at a moment when male writers were moving away from the genre" (3).

Part of the reason women turned to historical fiction in increasing numbers was that, beginning in the early decades of the twentieth century, women were permitted an education beyond that to which they previously had access. History became formally accessible to women scholars as it never had before. Moreover, as Wallace notes, it was during these early decades of the century that most western women began "entering into history as enfranchised citizens" (25), following the suffrage movements. The postmodern shift in historiography also played a role in making the historical genre particularly attractive to women writers. Hayden White's work on historiography in the 1970 s asserts that history and fiction are written in very similar ways: through a process White calls "emplotment," the historian studies a group of events and "begins to perceive the possible story form that such events may figure" (225; emphasis in original). That historical events are configured in terms of familiar narrative structures by the historian is not, in White's argument, an example of bad historiography; it is simply, as he says, "one of the ways that a culture has of making sense of both personal and public 
Feminist Historical Re-Visioning or "Good Mills and Boon"? Pivot 5.1

pasts" (225). The acknowledgment of the role of subjectivity in historiography has opened up space for the writing of "history from below," in E.P. Thompson's words (279), both in academic and literary contexts. Histories from below call attention to the ways in which factors such as gender, sexuality, race, and class have impacted the construction of established historical narratives. Such historical narratives are conveyed through voices previously denied access, including women's voices. If, as White argues, the historian controls the elisions, emphases, and biases of a historical narrative, it follows that there are alternate histories that have never been popularized because they could not or would not be written by those with the education and the platform to write and publish history.

The enduring importance of historical fiction to women readers and writers in the present century is easily illustrated by the ballooning catalogue of women's work in the genre. Librarian Sarah Johnson notes that, "between 2000 and 2007, approximately onethird of the Booklist 'Editors' Choice' titles in adult fiction were historical novels" (xv), and many of the best-known names in the genre at present belong to women, including Philippa Gregory, Diana Gabaldon, and Tracy Chevalier. In the past fifteen years, several other critical studies of women's work in historical fiction have followed Wallace's, including Susan Strehle and Mary Paniccia Carden's Doubled Plots: Romance and History (2003) and Katherine Cooper and Emma Short's The Female Figure in Contemporary Historical Fiction (2012). Yet, even as many literary critics acknowledge that women's historical novels are political in their self- 
Feminist Historical Re-Visioning or "Good Mills and Boon"? Pivot 5.1

reflexive ruminations on the relationship between gender and historiography, there are other voices that insist women's historical fiction is only loosely related to "real" history.

In a 2009 interview with the Daily Telegraph, noted British historian David Starkey asserted, "If you are to do a proper history of Europe before the last five minutes, it is a history of white males because they were the power players, and to pretend anything else is to falsify" (qtd. in Adams). History, in Starkey's view, is the territory of men: of the great men in history and the male historians and scholars who study them. Historical fiction, on the other hand, Starkey associates with women. In advance of the premiere of his four-part documentary Henry VIII: Mind of a Tyrant, Starkey made a series of disapproving remarks on contemporary historical fiction by women and the "feminised history" that it propagates. Considering the substantial number of Tudor historical novels that have been popular in recent years, he said, "[o]ne of the great problems has been that Henry, in a sense, has been absorbed by his wives. Which is bizarre" (qtd. in Adams). Notable throughout Starkey's statements is the relationship between genre and gender. Academic or nonfictional ${ }^{1}$ historiography is masculine, while historical fiction is feminine. Starkey, whose area of focus is Tudor history, urges us to recognize a clear and impenetrable distinction between the historical narratives he writes and those written by novelists like Philippa Gregory: "We really should stop taking historical novelists seriously as

\footnotetext{
${ }^{1}$ This term, too, we should view with suspicion in light of White's work comparing the writing of history to the writing of fiction.
} 
Feminist Historical Re-Visioning or "Good Mills and Boon"? Pivot 5.1

historians," he said in a 2013 interview, adding, "The idea that they have authority is ludicrous" (qtd. in Davies). In this latter interview, Starkey attempts to uphold a boundary between implicitly masculine academic historical narratives and implicitly feminine historical fiction by denouncing Gregory's bestselling Tudor series as nothing more than "good Mills and Boon." ${ }^{2}$ Historical fiction by women is considered inferior by Starkey, at least, in part, because of the association between women and romance and because of the perceived incompatibility of romance and "legitimate" history.

Contrary to Starkey's insistence on a division between the work of the historian and the work of the historical novelist, however, Philippa Gregory has insisted that there is not such a great difference between them. Following Starkey's "Mills and Boon" comment, Gregory reflected in a 2013 interview that "even a historian who prides himself on rectitude as much as Starkey, if you read his history of Elizabeth, you see the creation of a partly imaginary character" (qtd. in Kellaway). Indeed, though she frequently refers to the vast amounts of research she performs in preparation for writing a historical novel, Gregory is also quick to point out that, "when people critique historical fiction for accuracy, they forget we rarely know for sure what happened, so history books are often the best guess at the time" (qtd. in Wintle). A self-labelled feminist, Gregory has been candid in interviews about the fact that she sees her work as feminist historiography - that is, the practice of rewriting historical narratives

\footnotetext{
${ }^{2}$ Mills \& Boon was a major publisher of romance novels in the early to midtwentieth century. In 1971, it was acquired by Harlequin Enterprises of Canada. Starkey uses the name as a metonym for cheap formulaic romance novels.
} 
Feminist Historical Re-Visioning or "Good Mills and Boon"? Pivot 5.1

in order to foreground the previously minimized or one-dimensional representations of female figures: "The more research I do," Gregory says, "the more I think there is an untold history of women" (qtd. in Wintle). In another interview, she expresses her methodology as "reading the records with more sympathy, and with a feminist perspective" (Gregory, "Interview"). The paperback edition of The Other Queen includes another interview, in which Gregory again gestures to the feminist imperative in her work, stating, "I feel very strongly that history has mostly been written by men, and even when it is not prejudiced against women it is dominated by a male perspective and male morality" ("Conversation"). Although she hesitates to say that her novels have the effect of "putting the record straight," Gregory does present her Tudor novels as being a kind of feminist historiography intended to counter the androcentricity of capital-H history.

Is Philippa Gregory's work an example of revisionist "history from below" or is it, as Starkey insists, an example of "good Mills and Boon"? Finding a middle ground between Starkey's comments and Gregory's own, I suggest in this paper that Gregory's work belongs to neither category exclusively. Rather, Gregory's historical novels must be located at the intersection of the popular romance and the postmodern historical novel that writes history from below. In Starkey's evaluation, Gregory's novels are nothing more than cheap paperback romances designed to titillate readers and offer escapist fantasies. Yet it is undeniable that there is a greater amount of historical detail and precision in Gregory's novels than those of actual 
Feminist Historical Re-Visioning or "Good Mills and Boon"? Pivot 5.1

Mills and Boon historical romance authors, such as twentieth-century icons Georgette Heyer and Barbara Cartland. Gregory herself gestures towards the existence of a hierarchy in historical fiction in a Q\&A featured in the Touchstone edition of The Other Boleyn Girl. When asked to discuss the current popularity of the genre, Gregory asserts, "Very fine writers like Antonia Byatt, Rose Tremaine, and Margaret Atwood have written novels which have raised the standard of writing. Other writers, me among them, have raised the standards of research" ("Q\&A"). Indeed, Gregory's bibliographies, which appear at the ends of her novels, illustrate an effort to classify her novels in relation to academic historical narratives rather than pulp ones. The lists of texts used in the research of her Tudor books rarely include fewer than twenty books, and all of them, amusingly, cite David Starkey at least once. Thus, although there is plenty of sex and romance in Gregory's oeuvre, the author herself is keen to position her work as part of a literary, rather than pulp, brand of historical fiction.

Despite her emphasis on research and her claims of historical authenticity, however, Gregory's novels also foreground romance and eroticism, sometimes bending or outright disregarding historical facts to allow for the creation of romance narratives. It is precisely because of its use of romance formulas and tropes that one must be cautious about too liberally applauding Gregory's novels as examples of feminist historiography. Put simply, the post-structuralist argument that the historian shapes the history she or he writes through the very act of constructing a narrative does not mean that contemporary 
Feminist Historical Re-Visioning or "Good Mills and Boon"? Pivot 5.1

historiographers are necessarily more self-aware or reflective of their biases. If, on one hand, historiographers have the potential to write self-reflexive narratives that subvert hegemonic ideology, they also, on the other hand, have the potential to reaffirm conservative ideologies, to keep historical figures entrenched in superficial stereotypes, and to render the past as an exotic, spectacle-laden world ready to serve as the backdrop for contemporary readers' escapist fantasies. Using Gregory's bestselling novel The Other Boleyn Girl as a case study, this paper considers how emplotting history in accordance with the narrative tropes and characterizations that define the romance genre involves the adoption of ideologies about gender and sexuality that undermine the potential for subversive historiography.

\section{Historical Fiction and Romance}

While David Starkey seems to view history and romance as incompatible forms, Diana Wallace argues that the use of romance in the woman's historical novel is a strategy rather than a weakness. She asserts, "The transformation of history into romance allows the reinsertion of women's concerns" (20). Since women have often been kept within the domestic, private sphere, they have been absent or marginalized in historical narratives that focus on subjects usually associated with the public sphere: rulership, rebellion, war, and conquest. The traditional foci of the romance narrative - courtship, betrothal, marriage - allow for the representation of women's lived experiences and for the illustration of the connections between the 
Feminist Historical Re-Visioning or "Good Mills and Boon"? Pivot 5.1

personal and the political. From Wallace's perspective on the role of the romance in the woman's historical novel, it becomes clear that Starkey's rejection of the genre, particularly as utilized by women writers, signifies a desire to bar women from history and from historiography. Indeed, the fact that Wallace's 2003 study was the first to chart a literary genealogy of women's historical fiction suggests that the desire to exclude women from history through a dismissal of their historiographic work has been a consistent and ongoing concern. Yet, despite Wallace's embracing of romance as a strategy of feminist historiography, the romance has not had an easy relationship with feminism. Thus, while it is useful to consider, as Wallace does, that realism is not the only mode a historiographer might employ in order to make sense of history, the relationship between women's historical fiction, romance, and feminist historiography must not be oversimplified.

In defining the romance genre, it quickly becomes clear that historical romances and historical novels containing romances are not the same thing. As critic Pamela Regis explains, "The romance novel is a work of prose fiction that tells the story of the courtship and betrothal of one or more heroines" (14). Regis outlines eight narrative elements that she says define the romance novel: a depiction of corruption within society that the romance will reform; the meeting of heroine and hero; their attraction; a barrier to their relationship; a symbolic or literal death; the overcoming of the barrier; the declaration of love; and the betrothal (14). Furthermore, Regis notes that romance novels are defined by their happy endings (9) and their 
Feminist Historical Re-Visioning or "Good Mills and Boon"? Pivot 5.1

ingénue heroines (49). The virgin and the whore appear as standard archetypes in romance narratives, but, as Regis explains, the virginal ingénue is the usual heroine of a romance novel (49). This figure, according to Janice Radway, allows the "ideal romance" narrative to deal with female sexuality "by confining the expression of female desire within the limits of a permanent, loving relationship" (169). Indeed, the element of "love" is central to the ideal romance heroine. As Helen Hughes notes of the genre's typical heroine, "a woman who wants love is a sympathetic figure" (112). The ingénue's opposite the whore, seductress, or fallen woman - is a figure that severs the link between love and sex and is consequently denied the happy ending of matrimonial bliss granted to the heroine at the conclusion of the narrative. However, the ingénue figure need not be entirely passive. In Reading the Romance, Radway's study of the Smithton readers (a community of women readers of romance novels), she notes that the most highly recommended romances "are those with 'strong, ' 'fiery' heroines who are capable of 'defying the hero,' softening him, and showing him the value of loving and caring for another" (54). Yet it is paramount that, although she may be fiery or even rebellious throughout the narrative, the ideal romantic heroine like the hero she softens - will be firmly established in the rhetoric of love and monogamous matrimony by the narrative's conclusion, thus quelling the need for fiery rebellion.

When discussing historical fiction, however, one cannot simply apply these romance formulas to every historical novel that contains romantic elements. As numerous critics have noted (Radway, Regis, 
Feminist Historical Re-Visioning or "Good Mills and Boon"? Pivot 5.1

and Strehle among them), not all stories about love are "love stories." The term "historical romance" is imprecise and inadequate to describe a wealth of historical novels that contain romances, including some of the most iconic women's historical novels of the twentieth century, such as Margaret Mitchell's Gone with the Wind (1936) and Colleen McCullough's The Thorn Birds (1972). Thus, we need a different terminology to describe narratives that feature some, but not all, features of the romance novel. With this in mind, I suggest that many historical novels operate in a romantic mode, as opposed to being romance novels. The historical novel that is written in a romantic mode foregrounds at least one romantic relationship, and it often makes use of romance archetypes like the ingénue heroine and the Byronic hero and arranges these figures in romantic narrative patterns like the love triangle. However, this kind of novel also features elements usually omitted from the traditional romance novel: descriptions of bodily ailments and trauma like plague and syphilis, miscarriages, and births; graphic representations of violence, including battles, assassinations, and executions; and social corruption which remains unresolved by the novel's conclusion (which may not necessarily provide a happy ending). Historical novels that operate in the romantic mode use the foci of the romance in exactly the way Diana Wallace suggests: to foreground women's lives and women's histories. Yet, precisely because they are concerned with history, including less disputable facts such as marriages, divorces, and deaths, these novels do not always adhere to every aspect of the formula of the romance genre. For instance, while a novelist like 
Feminist Historical Re-Visioning or "Good Mills and Boon"? Pivot 5.1

Gregory might take advantage of her artistic licence in depicting a historical period, she is limited by the rules of the historical genre, which privilege realism and authenticity, or at least the guise of authenticity: she cannot write a "happily ever after" narrative for Henry VIII and Anne Boleyn.

Feminist critics have spent much time and ink engaging in archetypal analysis, pointing to the problems that occur when narrative archetypes - simplifications of identity that they are - come to be accepted as the realities of female subject positions. Feminist discourse has shown the ways in which patriarchal society, buoyed by representations of women in popular culture, makes space for only two understandings of women: the valorized virgin and the desired but detested whore. As Jane Caputi explains, the madonna/whore dichotomy signals "a sexual double standard . . . one that allows men greater sexual latitude, defines women in relation to men, and splits women into pure or dirty, 'virgins' or 'whores,' 'keepers' or 'trash,' good 'goods' or 'damaged goods'" (314). Moreover, many feminist critics of the romance express the view that "the romance novel straightjackets the heroine by making marriage the barometer of her success" and that it "sends a message to readers that independent, questing women are actually better off destroyed" (Regis 11).

The work that feminist literary critics have done to unpack the troubled relationship between feminist politics and the popular romance narrative - both textual and visual - is extensive. It should be noted that, while many critics are pessimistic about the romance form, many others argue for reading romances in ways that 
Feminist Historical Re-Visioning or "Good Mills and Boon"? Pivot 5.1

potentially empower women readers and writers. Reflecting on the myriad positions that feminist literary critics have taken up in relation to the subject of the romance, Joanne Hollows summarizes: "If feminist critics cannot align their feminism with the romance, then it seems that the romance cannot completely come to terms with feminism" (83). A great deal of the tension between feminism and the romance, I suggest, lies in the fact that the romance's formulaic female archetypes represent precisely the static female identity positions that feminism has long fought to undermine: the madonna and the whore. In terms of historical romances like those Gregory writes, the tension lies in the conflicting narrative strategies of feminist historiography (which aims to undermine stereotypical representations of women) and the popular romance (which relies on stereotypes or, more properly, literary archetypes) for the creation of a familiarly plotted genre narrative.

\section{Blending "History from Below" with Historical Romance in The Other Boleyn Girl}

Philippa Gregory, like any writer of historical narrative, interprets data, invents explanations for gaps or ambiguities in the historical record, and makes decisions about emplotment, which includes deciding what to omit and what to emphasize. From one perspective, these narrative decisions are what allow Gregory to write gynocentric history. On the other hand, despite the work she does to foreground the central roles women played, many of Gregory's novels rely on narrative archetypes connected to the romance genre that position 
Feminist Historical Re-Visioning or "Good Mills and Boon"? Pivot 5.1

female characters as love-triangle rivals in madonna/whore binaries. In The Other Boleyn Girl, for instance, Gregory positions the naïve and loving Mary Boleyn against the scheming temptress Anne Boleyn. Anne is also the rival to Katherine of Aragon, whose innocence and faithfulness are her defining characteristics. What is important to note is that these madonna/whore binaries do not arise organically from history. Historian Retha Warnicke cautions that, "in histories that treat men as three-dimensional and complex personalities, the women shine forth in universal stereotypes: the shrew, the whore, the tease, the shy virgin, or the blessed mother" (57). ${ }^{3}$ This sentiment is echoed by Antonia Fraser, who opens The Wives of Henry VIII by noting, "their characters are popularly portrayed as female stereotypes: the Betrayed Wife, the Temptress, the Good Woman, the Ugly Sister, the Bad Girl, and finally, the Mother Figure" (1). Yet these archetypes have proven irresistible to both historians and historical novelists alike.

While many of the rivalries Gregory represents are supported by historical documents, she makes particular choices through her language, emplotment, and characterization which emphasize the idea that there are two kinds of women - madonnas and whores and that these two kinds of women are always in competition. Moreover, Gregory's Tudor series as a whole strongly suggests the superiority of the innocent ingénue - i.e., the patriarchal ideal of femininity - since these are the women who are represented most

${ }^{3}$ Somewhat ironically, Gregory credits Retha Warnicke with influencing her depictions of Anne Boleyn and Anne of Cleves in the notes included at the ends of both The Other Boleyn Girl and The Boleyn Inheritance. 
Feminist Historical Re-Visioning or "Good Mills and Boon"? Pivot 5.1

sympathetically. Maternity, devotion, and preference for family life over court life are held up as ideal qualities in women through characters such as Mary Boleyn and Katherine of Aragon. In contrast, ambition and pleasure-seeking are shown as insidious qualities, generating little sympathy for figures like Anne Boleyn. Without pretending that such a thing as objective history exists, I nevertheless suggest that Gregory's construction of madonna/whore rivals in love triangles is problematic if one is to take the series as an example of feminist historiography. By analyzing the narrative construction of virgins and whores in The Other Boleyn Girl, I point to the ways in which her novel exists in tension between the formulas of the traditional romance narrative and Gregory's own explicitly stated interest in feminist revisionist historiography.

The Other Boleyn Girl, Gregory's first published Tudor novel, focuses on the relationship and rivalry between Mary and Anne Boleyn from 1521 until Anne's execution in 1536. Indeed, the title itself signals the structural pattern of rival, oppositional female figures at the centre of the novel. One of the most famous women in English history, Anne Boleyn was the second wife of Henry VIII. Gregory's story, however, sheds light on the life of Anne's less famous sister, Mary, who was mistress to Henry VIII for some time before the king and Anne began their relationship and while Henry was still married to Katherine of Aragon. The premise of focalizing history through a marginalized female figure immediately suggests a project of feminist historiography, the excavation of women's histories that have often been omitted from dominant historical narratives. The novel's central 
Feminist Historical Re-Visioning or "Good Mills and Boon"? Pivot 5.1

narrative thread is the rivalry between these two sisters to be the favourite - of the family, of the king, and of the court. To be "the other Boleyn girl" in the novel is to be invisible, overlooked, and powerless. At the same time, though, the title comments metafictionally on the fact that its narrator and protagonist is a woman who has been forgotten in cultural memory at the time of the novel's publication. Yet, because The Other Boleyn Girl is written as a historical romance centering on the competition between two sisters to be the better married Boleyn girl, Gregory's characterizations fall somewhat short of being truly subversive representations of women, instead reverting to the familiar archetypes of the whore and the ingénue of romantic love triangles.

Mary and Anne are represented in The Other Boleyn Girl as opposites who are nevertheless two sides of the same coin. Throughout the novel, their brother George frequently refers to them as Annamaria and Marianne, emphasizing their inextricable, yet oppositional, connection to one another. In order to establish a clear distinction between two women who are remembered primarily for their sexual relationships with a king, Gregory characterizes them as deploying their sexuality in entirely different ways. Gregory's Mary is a mistress who believes herself to be deeply in love with Henry. Their sexual relationship produces two children, and her identity in the second half of the novel is largely informed by her role as a devoted mother. In contrast, Gregory's Anne is a mistress who uses sexuality - or the withholding of it - as a tool for her own ambitions. Moreover, she is a woman to whom maternal feeling does not come easily. 
Feminist Historical Re-Visioning or "Good Mills and Boon"? Pivot 5.1

Ultimately, Gregory's novel privileges the point of view of the loving, dutiful, and maternal woman, asserting the superiority of this kind of femininity over the ambitious, analytical, and self-preserving behaviours exhibited by Anne.

As historian Alison Weir explains, there has been a centuries-long debate about the nature of Mary Boleyn's relationship with the king, especially since the affair was "conducted so discreetly that there is no record of the date it started, its duration, or when it ended" (Mary Boleyn 114-15). However, as historians excavated Henry's private life over time, they uncovered "overwhelmingly conclusive" evidence that the affair between Henry and Mary did, indeed, take place (115). Yet, while she depicts Mary Boleyn as a mistress of Henry VIII, Gregory's representation of Mary before and during the start of her affair with Henry differs somewhat from the accounts laid down by academic historians. In particular, there is evidence to suggest that Mary Boleyn may have had a reputation as a licentious woman during her life. Weir mentions that she was reported by some to have been the mistress of King Francis during her time in France (72). ${ }^{4}$ And, in The Wives of Henry VIII, Antonia Fraser characterizes Mary as "a high-spirited, rather giddy girl who enjoyed all the pleasures of the court on offer - including the embraces of the King" and notes that "when she was fifteen she had gone to the French court in the train of Princess Mary Tudor where she had acquired an extremely wanton reputation" (101).

\footnotetext{
${ }^{4}$ Weir does, however, trouble these claims in Mary Boleyn: Mistress of Kings, noting that history has often remembered Mary Boleyn without referring to solid evidence.
} 
Feminist Historical Re-Visioning or "Good Mills and Boon"? Pivot 5.1

Gregory's Mary, in stark contrast to these accounts, is represented as an ingénue at the start of The Other Boleyn Girl. As she contemplates Henry's sexual expectations, she tells her siblings, "I don't know how to do it . . . William did it once a week or so, and that in the dark, and quickly done, and I never much liked it. I don't know what it is I am supposed to do" (33). In Gregory's narrative, although she is married and thus not a virgin, Mary is nevertheless established as sexually inexperienced. Her innocence is further solidified when Mary assures Henry that she is not interested in him merely as a means of social climbing: "I promise you, it's no game to me, Your Majesty" (45). As the affair blossoms, Mary declares herself "a girl of fourteen in love for the first time" (64) and asserts, "I want the man. Not because he's king" (72). Later, when Henry shifts his affections to Anne, Mary is heartbroken, and Gregory takes care to illustrate that her despair is not for the loss of wealth or status but for the loss of Henry's love, which she believed to be true: "for the first time in all the long while that I had been his lover I felt like a whore indeed, and it was my own sister who shamed me" (264). Gregory's Mary is constructed as the typical ingénue heroine of the romance novel, ready for her romantic - and sexual - awakening at the start of the narrative.

In contrast, Gregory represents Anne as a cunning woman for whom sex and love are not necessarily connected. Anne's sexuality is established in Gregory's novel even before she takes up as Henry's lover. Early in the novel, Anne contrives to wed and consummate a marriage with Henry Percy, a plot point Gregory utilizes to suggest 
Feminist Historical Re-Visioning or "Good Mills and Boon"? Pivot 5.1

that Anne has already attempted to use sex in order to advance her social position. Describing her plan to Mary, Anne explains, "Not even the Percy family will be able to wriggle out of it when Henry and I tell them that we are wedded and bedded" (133). Gregory's Anne can only feign the romantic idealism that comes so naturally to Mary. Her relationships are all about ambition and strategy. For instance, she tells Percy, "Love is all that matters. At any rate, that's what I think" (101), but, when Mary challenges this sentiment as a lie in the very next scene, Anne smiles and says, "I wish you would take the trouble to see who I am talking to, and not what I am saying" (101).

Gregory's Anne thinks of a husband primarily as a means of acquiring status. She laments being single because "I have no husband who can be given land to show the king's favour. I have no husband to win high office because my sister is the king's mistress . . . However high you rise I still get nothing" (122).

In contrast to Gregory's representation of Anne's first attempt at social climbing through seduction, many historians present a vastly different account of the relationship between Anne and Henry Percy. David Starkey, Alison Weir, and Neville Williams all suggest that Anne and Henry Percy were in love and wanted to marry, but the king had already noticed Anne and tasked Cardinal Wolsey with preventing Percy from marrying her (Starkey 275-76; Weir, Henry VIII 240; Williams 106). This narrative differs significantly from Gregory's by suggesting that Henry VIII was the one who set out to seduce Anne, eliminating Percy in order to claim her for himself. Gregory's narrative, on the other hand, characterizes Anne as the aggressor, 
Feminist Historical Re-Visioning or "Good Mills and Boon"? Pivot 5.1

waiting to entrap a man of wealth and status through seduction. This crucial difference between Gregory's historical narrative and those of Starkey, Weir, and Williams illuminates the way Gregory's narrative choices construct Anne as the cunning manipulator and Henry as the object of her seductive gaze, differentiating Anne from her predecessor, the unwitting and naïve Mary.

Throughout the first half of the novel, while Mary is Henry's mistress, Anne routinely gives sage, though highly cynical, advice to her sister. In these speeches, Anne positions herself as a strategic rather than emotional lover, telling Mary,

You are all ready for the pleasures of bed and board. But the woman who manages Henry will know that her pleasure must be in managing his thoughts, every minute of the day. It would not be a marriage of sensual lust at all, thought Henry would think that was what he was getting. It would be an affair of unending skill. (54)

She criticizes Mary for enjoying her relationship with Henry and cautions her not to lose herself in fantasies of love and forget that she is there to please the king. Indeed, during Mary's first pregnancy, Anne warns, "No woman has ever kept a man by giving him children . . . You can't stop pleasing him just because he's got a child on you" (193). In keeping with her view of sex and romance as tools of manipulation, Anne's later relationship with Henry is represented as a carefully crafted game of cat and mouse. The advice that Anne has given Mary all along is now leveraged to her own benefit. She seduces Henry not for her own pleasure but for the social status and power 
Feminist Historical Re-Visioning or "Good Mills and Boon"? Pivot 5.1

that he bestows upon her in return for the pleasure she gives him. The challenge for Anne, as her courtship with Henry continues, is to keep him desirous of her without giving in to the point that he can cast her off as he did Katherine and Mary. As she explains to her sister, "I have to do something to keep him hot for my touch. I have to keep him coming forward and hold him off, all at the same time" (326). The difference between Anne and Mary as mistresses is that Mary gives her sexuality out of love, whereas Anne seeks to use "whore's tricks" (326) in order to manipulate Henry and raise her own social status.

In recent decades, historians of female-focused academic histories have challenged the prevailing representations of Anne Boleyn. Antonia Fraser notes that she is usually presented as a "temptress" (1), and Retha Warnicke refers to the typical image of Anne as "an aggressive woman, who manipulated or bewitched Henry VIII into ending his union with Catherine of Aragon" (xi). Both historians have thus attempted to add nuance to the historical treatment of Anne Boleyn. Warnicke, for her part, is conscious of the role that stereotypes and archetypes play in historical narratives, and she works to prevent her representation of Anne from falling too neatly into familiar narrative patterns. Her study ultimately argues that "the modern conception of [Anne Boleyn] as a femme fatale must be discarded" ( 5 ; italics in original). With this assertion, Warnicke succinctly points to the way that literary archetypes like the femme fatale sometimes emerge in historiography as a means of simplifying complex individuals into easily recognizable forms. Yet, in The Other 
Feminist Historical Re-Visioning or "Good Mills and Boon"? Pivot 5.1

Boleyn Girl, Anne's complexities are largely elided. There is nothing particularly subversive about Gregory's representation of Anne: instead, she is represented much as she has been for centuries - as wanton and depraved. Like the archetypal femme fatale, Gregory's Anne is shameless with her body and her sexuality, even kissing her brother passionately on the mouth (392) and letting him see her in the nude (411). Gregory goes so far as to suggest an instance of incestuous sex between Anne and George, a desperate attempt to produce a viable child to present to Henry (564). While George and Anne were, indeed, accused of incest, modern historians have discounted the validity of the charge, pointing to the feebleness of the evidence against them (Fraser 252; Starkey 580). That Gregory chooses to depict the incest as true reflects her manipulation of the historical record in order to construct Anne as the archetypal femme fatale in contrast to her ingénue sister.

Meanwhile, Mary becomes increasingly aligned with Katherine of Aragon, Henry's first wife, as an embodiment of the ideal "good" wife. When Henry's affections shift from Mary to Anne, Mary finds herself sharing a moment of camaraderie with Katherine as they joke about Anne's attempts to convince the king of her fragility and demureness. Linked as Henry's cast-offs, Katherine and Anne share intimate knowledge of Anne's nature and her methods of dissembling, and Mary becomes increasingly sympathetic to Katherine as Anne's stock continues to rise. After receiving a triumphant letter from her sister, Mary reflects: 
Feminist Historical Re-Visioning or "Good Mills and Boon"? Pivot 5.1

Nothing would be the same for any woman in this country again. From this time onward no wife, however obedient, however loving, would be safe. For everyone would know that if a wife such as Queen Katherine of England could be put aside for no reason, then any wife could be put aside. (276) And Mary continues throughout the novel to hold up Katherine as the epitome of the ideal wife. During a trial in the spring of 1529 , she watches in passionate solidarity as Katherine challenges the king's attempt to put their marriage aside: "I was near to delighted laughter because Katherine of Aragon was speaking out for the women of the country, for the good wives who should not be put aside just because their husbands had taken a fancy to another" (316-17; emphasis added). Mary not only idolizes Katherine but also she extols the model of the obedient, devoted wife and mother following the end of her affair with Henry.

Reasonably, then, Gregory depicts Mary in the second half of the novel as a devoted mother who continually asks to be sent away from court in order to be with her children at Hever. During one exchange, Mary's mother accuses her of being "dull," and Mary explains that she is depressed about being separated from her children: "I cannot make myself merry any more. I have lost my joy. I have lost my joy. And no one but me even knows what this feels like, and how dreadful it is" (204). This maternal devotion allows Mary's family and sister to manipulate her, baiting her with the promise of visits with her children to compel her to do their bidding. Indeed, Gregory has Anne take in Mary's son Henry as her ward in order to control her sister. 
Feminist Historical Re-Visioning or "Good Mills and Boon"? Pivot 5.1

But Warnicke's account of how Henry Carey came to be Anne's ward differs. Where Gregory depicts Anne taking away Mary's eldest child as a means of keeping her sister servile and malleable to Anne's indomitable will, Warnicke refers to a letter from King Henry to Anne in which he refers to the "'extreame necessity' of William's widow" (82) and alludes to damning gossip about Mary. In Warnicke's account, Anne becomes the protector of her nephew following William Carey's death at a time when Mary and her offspring were particularly vulnerable. Indeed, Warnicke notes that Henry Carey "benefited enormously from his position as ward of the queen" (148).

Gregory's narrative, however, presents no such benefits to young Henry and uses Mary's separation from her son to advocate for the importance of the mother-child bond. Even when Gregory begins to establish the central romance of the book - that of Mary and William Stafford - she is quick to remind the reader of Mary's maternal devotion. Following a chapter that establishes Mary and William's sexual relationship, Mary concludes by asserting that "more than anything else I wanted to sleep the next half year away until I could go to Hever and see my children again" (437). Mary's maternity is thus deployed as one of the primary means of differentiating and opposing her to Anne. After giving birth to her first child, Elizabeth, one of Anne's first remarks conveys (ironic) disappointment: "A girl. What good is a girl to us?" (487). Unlike Mary, who consistently yearns to be with her children, Anne makes plans to send Elizabeth away almost immediately (488). Thus, while both women serve as mistresses to the king, Gregory's Mary is cast as the madonna figure 
Feminist Historical Re-Visioning or "Good Mills and Boon"? Pivot 5.1

who embraces her role as mother rather than continuing to prioritize sexuality and politics.

In addition to her maternal characterization, Mary's relationship with William Stafford is the novel's central romance, and it establishes Mary as the conventional romantic heroine for whom love and marriage restore balance to a chaotic social world. While most accounts confirm that Mary and William Stafford married for love, Gregory emphasizes and idealizes their romance somewhat more than is corroborated by the historical record. For instance, immediately following the ending of The Other Boleyn Girl, Gregory's author's note begins by assuring the reader that "Mary and William Stafford did live a long and happy life at Rochford" (663). In this way, she emphasizes the "happily ever after" element of the romance plot over the novel's otherwise grim conclusion, which ends shortly after the executions of Anne and George Boleyn. Yet there is a note of falseness in Gregory's allusion to the "long" marriage of William and Mary: Mary died in 1543 , only nine years after they married and seven years after the events of the book's final chapter. Indeed, the fact that Mary did not live a long life is supported by the fact that William outlived her by more than a decade, remarrying in 1552 and producing five children with his second wife before dying in 1556 (Weir, Mary Boleyn 254$55)$. Weir goes on to say of Mary that "we might even speculate that the stresses and tragedies of the past decade had hastened her end" (250). Gregory's author's note, therefore, functions as part of the romance narrative she constructs from the events and figures of Tudor history. 
Feminist Historical Re-Visioning or "Good Mills and Boon"? Pivot 5.1

This pronounced romanticization of history is at odds with the self-proclaimed feminist imperative of Gregory's work. Early in the novel, Elizabeth Boleyn, Mary and Anne's mother, points out, "There is no freedom for women in this world, fight or not as you like. See where Anne has brought herself" (145). On the one hand, sentiments like this within the text signal a feminist historiographical approach that emphasizes the ways in which women have been oppressed, historically, under patriarchy. Yet, on the other hand, Elizabeth Boleyn's outlook - coupled with the Anne's unsympathetic portrayal and a happy ending that hinges on Mary's marriage to William Stafford - suggests that for a woman to fight patriarchal oppression, as Anne does, is a futile endeavour. Indeed, the narrative centrality of Mary and William's marriage and their escape from court reveals the novel's emphasis on the nuclear, patriarchal family unit and the conservative ideology that often accompanies it. William's idealized image of Mary as his wife entails her working in the kitchen, skinning chickens and making cheese $(404 ; 418)$ - in other words, firmly contained within the home and the domestic role expected of a wife. This is what he offers when he proposes marriage: not a way for her to subvert the ideology that oppresses women, but a way to, as Mary Wollstonecraft would say, "adorn its prison" (157).

The problem, I argue, is not that Gregory represents the virgin and the whore as the two archetypes by which society classifies women; the problem is that her novel uses precisely this same system of classification, and it upholds a moral lesson for its readers about which model of womanhood is to be emulated and which is to 
Feminist Historical Re-Visioning or "Good Mills and Boon"? Pivot 5.1

be condemned. And Gregory is not alone in espousing this sense of proper femininity. Even Alison Weir concludes her biography of Mary Boleyn with moralizing remarks on love and priorities, asserting that, "unlike her sister, Mary had not tempted fate too far," that she "had learned what really mattered in life" and "found love and stability" (252). Perhaps the appeal of the romance narrative to historiographers is its orderliness, its prevalence speaking to a desire to understand historical figures by reducing complex individuals into essential archetypes. Ultimately, in The Other Boleyn Girl, Gregory's narrative account of Anne Boleyn is more cautionary tale than feminist re-visioning, and Mary Boleyn emerges as the romantic ideal to be celebrated.

\section{Selling and Selling Out}

The Other Boleyn Girl employs the archetypes and formulas of the romance genre with such consistency that one cannot help feeling beaten over the brow by its lesson on being a "good wife," that superior female figure revered by romantic narratives both literary and historical. Through her adherence to romance formulas and archetypes, Gregory has emplotted history in a way that dichotomizes female figures as madonnas and whores and idealizes the figure of the "good wife" and mother. This way of characterizing women is rather standard across romance narratives. As Janice Radway states, "this literary form reaffirms its founding culture's belief that women are valuable not for their unique personal qualities but for their biological sameness and their ability to perform that essential role of 
Feminist Historical Re-Visioning or "Good Mills and Boon"? Pivot 5.1

maintaining and reconstituting others" (208). Yet, in light of Philippa Gregory's own comments positioning her historical novels within feminist historiography, the extent to which her novels simplify female subject positions into madonnas and whores is surprising and reveals the limits of the relationship between feminism and popular fiction.

In her study of popular romances, Tania Modleski emphasizes the presence of small resistances in romance narratives, arguing that "even the contemporary mass-produced narratives for women contain elements of protest and resistance underneath highly 'orthodox' plots" (25). Similarly, in her treatment of Gregory's Wideacre trilogy, Diana Wallace focuses on the subversive Marxist feminist elements of the novels, only briefly noting the tension that exists between this political discourse and "the conservative sexual politics of the typical family saga and the glamorization of female suffering in the typical erotic historical" (187). Yet to focus on the subversive qualities of a narrative without considering the significance of its overtly conservative form is to conduct a limited analysis. In The Feminist Bestseller, her study of the relationship between feminist politics and popular novels by women, Imelda Whelehan opines that "the question of whether these books and their writers are 'selling out' is a difficult one to answer" (14), and a difficult question it is indeed. Part of the feminist literary critic's agenda is to reclaim and appreciate the works of women writers, especially those that are usually dismissed as subpar. There is an understandable desire to defend and praise these women's novels that have been often unfairly relegated to the low 
Feminist Historical Re-Visioning or "Good Mills and Boon"? Pivot 5.1

end of a literary hierarchy. However, the question of when "selling" (being popular) becomes "selling out" (appropriating patriarchal ideology in order to be popular) must not be ignored or downplayed. While there are moments of feminist protest and resistance in The Other Boleyn Girl, the novel as a whole represents a largely patriarchal and conservative reflection on women and their social positions. Ultimately, the problem with the feminist claims Gregory has made regarding her novel lies in the fact that she has not simply represented how women have been historically stereotyped as either madonnas or whores; rather, she has appropriated precisely these binaristic, patriarchal understandings of female subjectivity and presented them unironically to the modern-day reader.

While commercial imperative undermines the political subversiveness of Gregory's historical novel, its popularity - due in large part to its familiar and conventional narrative formula - is also the site of its subversive potential. The popularity of the woman's historical novel is precisely what offers writers the chance to disseminate alternate, feminist historical narratives to mass readerships. "History from below" that is written but not widely read has little chance of subverting dominant narratives and ideologies; a novel cannot subvert prevailing views if it is not read. But to be read - to be visible - often requires concessions to commercial interests. In order for her work to be popular and widely consumed, Gregory adheres to familiar and enduring forms like the romance narrative. But it is this very form that often undermines the subversiveness of the women's histories she presents. The Other Boleyn Girl exists at 
Feminist Historical Re-Visioning or "Good Mills and Boon"? Pivot 5.1

this site of tension between the popular romance narrative and the postmodern "history from below." Presenting a challenge to masculinist views of history, like those espoused by David Starkey, Gregory's novel encourages readers to reflect on whose histories are told and remembered. Yet, at the same time, the use of romance tropes to tell these marginalized women's histories does not do much to undermine the stereotypes and two-dimensional representations of women in history. Less frequently represented women like Mary Boleyn, Anne of Cleves, Mary Tudor, and Amy Dudley have been rendered more visible in the popular remembrance of history because of their presence in Gregory's novels. Yet how they are remembered is just as politically important as whether they are remembered.

\section{Works Cited}

Adams, Stephen. "History Has Been 'Feminised' Says David Starkey as He Launches Henry VIII Series." Telegraph 30 Mar 2009. Web. 30 Mar. 2014.

Caputi, Jane. "The Pornography of Everyday Life." Gender, Race, and Class in Media: A Critical Reader. 3rd ed. Ed. Gail Dines and Jean M. Humez. Thousand Oaks: Sage, 2011. 307-20. Print.

Cooper, Katherine, and Emma Short, eds. The Female Figure in Contemporary Historical Fiction. Basingstoke: Palgrave Macmillan, 2012. Print.

Davies, Serena. "David Starkey: It Is 'Ludicrous' to Suggest that Historical Novelists Have Authority." Telegraph 11 May 2013. Web. 22 March 2015. 
Feminist Historical Re-Visioning or "Good Mills and Boon"? Pivot 5.1

Fraser, Antonia. The Wives of Henry VIII. London: Viking, 1992. Print. Gregory, Philippa. "A Conversation with Philippa Gregory." The Other Queen. New York: Touchstone, 2009. n.pag. Print.

---. "An Interview with Philippa Gregory." BookBrowse. BookBrowse, n.d. Web. 21 April 2014.

---. The Other Boleyn Girl. New York: Touchstone, 2003. Print.

---. "Q\&A with Philippa Gregory, Author of The Other Boleyn Girl." The Other Boleyn Girl. New York: Touchstone, 2003. n.pag. Print.

Gristwood, Sarah. Elizabeth and Leicester: Power, Passion, Politics.

New York: Viking, 2007. Print.

Hollows, Joanne. Feminism, Femininity, and Popular Culture.

Manchester: Manchester UP, 2000. Print.

Hughes, Helen. The Historical Romance. London: Routledge, 1993.

Print.

Johnson, Sarah L. Historical Fiction II: A Guide to the Genre.

Westport: Libraries Unlimited, 2009. Print.

Kellaway, Kate. "Philippa Gregory: Unearthing History's Forgotten

Women." Guardian 28 July 2013. Web. 22 Mar. 2015.

Modleski, Tania. Loving with a Vengeance: Mass-Produced Fantasies

for Women. Hamden: Archon, 1982. Print.

Radway, Janice. Reading the Romance: Women, Patriarchy, and

Popular Literature. Chapel Hill: U of North Carolina P, 1984. Print. Regis, Pamela. A Natural History of the Romance Novel. Philadelphia:

U of Pennsylvania P, 2003. Print. 
Feminist Historical Re-Visioning or "Good Mills and Boon"? Pivot 5.1

Rich, Adrienne. "When We Dead Awaken: Writing as Re-Vision." Adrienne Rich's Poetry and Prose. Ed. Barbara Charlesworth Gelpi and Albert Gelpi. New York: Norton, 1993. 166-77. Print.

Starkey, David. Six Wives: The Queens of Henry VIII. New York: Harper Collins, 2003. Print.

Strehle, Susan, and Mary Paniccia Carden, eds. Doubled Plots:

Romance and History. Jackson: UP of Mississippi, 2003. Print.

Thompson, E.P. "History from Below." Times Literary Supplement 7 Apr. 1966: 279. Print.

Wallace, Diana. The Woman's Historical Novel: British Women Writers, 1900-2000. Basingstoke: Palgrave Macmillan, 2005.

Print.

Warnicke, Retha. The Rise and Fall of Anne Boleyn: Family Politics at the Court of Henry VIII. Cambridge: Cambridge UP, 1989. Print. Weir, Alison. Henry VIII: The King and His Court. New York: Ballantine, 2001. Print.

---. Mary Boleyn: The Mistress of Kings. Toronto: McClelland and Stewart, 2011. Print.

Whelehan, Imelda. The Feminist Bestseller: From Sex and the Single Girl to Sex and the City. Basingstoke: Palgrave Macmillan, 2005. Print.

White, Hayden. "The Historical Text as Literary Artifact." The History and Narrative Reader. Ed. Geoffrey Roberts. New York:

Routledge, 2001. 211-20. Print.

Williams, Neville. Henry VIII and His Court. New York: Macmillan, 1971. Print. 
Feminist Historical Re-Visioning or "Good Mills and Boon"? Pivot 5.1

Wintle, Angela. "Philippa Gregory on The White Queen, Game of Thrones and Her Childhood." Telegraph 15 Aug. 2014. Web. 22 March 2015.

Wollstonecraft, Mary. "A Vindication of the Rights of Woman." The Vindications: The Rights of Men and the Rights of Woman. Ed. D.L. Macdonald and Kathleen Scherf. Peterborough: Broadview, 1997. 99-343. Print.

Victoria Kennedy is a doctoral candidate at Wilfrid Laurier University in Waterloo, Ontario. She specializes in women's writing and gender theory and is currently researching contemporary historical fiction by women for her SSHRCfunded dissertation project. Her research examines the tensions between feminist historiography and narrative pleasures in popular historical novels by writers such as Philippa Gregory and Diana Gabaldon.

Return to contents (LINK) 